\title{
Cultural Participatory in Tourism Digital Marketing Communication Channel
}

\section{Budaya Partisipatori dalam Saluran Komunikasi Pemasaran Digital Pariwisata}

\author{
Riris Loisa ${ }^{1}$, Diah Ayu Candraningrum ${ }^{2}$, Lusia Savitri Setyo Utami ${ }^{3}$, Lydia Irena $^{4}$ \\ ${ }^{1}$ Fakultas Ilmu Komunikasi, Universitas Tarumanagara, Jln Letjen S. Parman No. 1, Jakarta* \\ Email: ririsl@fikom.untar.ac.id \\ ${ }^{2}$ Fakultas Ilmu Komunikasi, Universitas Tarumanagara, Jln Letjen S. Parman No. 1, Jakarta \\ Email:diahc@fikom.untar.ac.id \\ ${ }^{3}$ Fakultas Ilmu Komunikasi, Universitas Tarumanagara, Jln Letjen S. Parman No. 1, Jakarta \\ Email:lusias@fikom.untar.ac.id \\ ${ }^{4}$ Fakultas Ilmu Komunikasi, Universitas Tarumanagara, Jln Letjen S. Parman No. 1, Jakarta \\ Email: lydiairena@gmail.com
}

Masuk tanggal : 30-09-2021, revisi tanggal : 30-11-2021, diterima untuk diterbitkan tanggal : 03-12-2021

\begin{abstract}
Tourism is one of Indonesia's leading sectors that has been seriously affected by the pandemic. This study aims to describe participatory culture in digital tourism marketing communication channels during the pandemic, through Instagram social media channels from micro-influencers, that focus on three priority tourism destinations that have been set by the government. By using the Participatory Media Culture Theory from Henry Jenkins, it is further studied how consumers and producers create cultural artifacts with commodity value. The research applied a netnographic method, the data were gathered and analyzed by the social media analysis application Analysis.io. The subject of research is the influencers and followers in 3 (three) Instagram accounts: @explorejogja, @indraseptianazhari, and @ travelwithgerie, while the object of the research was the forms of participation as cultural artifacts in these accounts This study concludes that the participants build a participatory culture by the power of visual and narrative artifacts, as well as their spreadability. Further this research shows that (1) cultural artifacts in each account have their own characteristics, with similarities in the prosumer participation, where reposting becomes a cultural artifact that has its own power to form virtual relationships; (2) attractive visuals and informal guides in the form of narratives are also cultural artifacts that invite further involvement of participants, in the form of likes, comments, reposts, etc.; and (3) the presence of micro-influencers who are inherently intertwined with these accounts jointly contributing to the dissemination of content and their respective accounts, which in turn becomes a force for the spread of tourism marketing, especially during the pandemic.
\end{abstract}

Keywords: digital marketing communication channels, participatory culture, tourism

\begin{abstract}
Abstrak
Pariwisata adalah salah satu sektor unggulan Indonesia yang terkena dampak serius dari pandemi ini. Penelitian ini bertujuan untuk mendeskripsikan budaya partisipatif dalam saluran komunikasi pemasaran pariwisata digital selama pandemi, melalui saluran media
\end{abstract}


sosial Instagram dari mikro-influencer, yang berfokus pada tiga destinasi wisata prioritas yang telah ditetapkan oleh pemerintah. Dengan menggunakan Teori Budaya Media Partisipatif dari Henry Jenkins, lebih lanjut dipelajari bagaimana konsumen dan produsen menciptakan artefak budaya dengan nilai komoditas. Penelitian ini menggunakan metode netnografi, data dikumpulkan dan dianalisis dengan aplikasi analisis media sosial Analysis.io. Subjek penelitian adalah influencer dan followers di 3 (tiga) akun Instagram: @explorejogja, @indraseptianazhari, dan @ travelwithgerie, sedangkan objek penelitian adalah bentuk partisipasi sebagai artefak budaya dalam akun tersebut. Penelitian ini menyimpulkan budaya partisipatori dibangun dengan kekuatan artefak visual dan naratif, serta daya sebarnya. Lebih lanjut, penelitian ini menunjukkan bahwa (1) artefak budaya di setiap akun memiliki ciri khas tersendiri, dengan kesamaan berupa partisipasi prosumer, dimana reposting menjadi artefak budaya yang memiliki kekuatan untuk membentuk hubungan virtual; (2) visual yang menarik dan panduan informal berupa narasi juga merupakan artefak budaya yang mengundang keterlibatan peserta lebih lanjut, dalam bentuk ekspresi rasa suka, komentar, repost, dll; dan (3) kehadiran micro-influencer yang secara inheren terjalin dengan akun-akun tersebut secara bersama-sama berkontribusi dalam penyebaran konten dan akunnya masing-masing, yang pada akhirnya menjadi kekuatan bagi penyebaran pemasaran pariwisata, khususnya di masa pandemi.

Kata Kunci: budaya partisipatori, pariwisata, saluran komunikasi pemasaran digital

\section{Introduction}

Tourism is one of Indonesia's leading sectors that presents an extraordinary pandemic. The Indonesian Hotel and Restaurant Association (PHRI) stated that until the first quarter of 2020, Indonesia's tourism industry suffered losses of Rp 85.7 trillion (Putra, 2017). Data from the Central Statistics Agency shows a drastic decline in tourist visits during the pandemic. In the first semester of 2019, foreign tourist visits reached 7.72 million. When the pandemic broke out in Indonesia in the mid of 2020, there was a decrease in visits by 59.96 percent from the previous year, foreign tourists visit only reached 3.13 million. In the first semester of 2021, this figure decreased even more sharply, to only 802.38 thousand visits, a decrease of 74 percent (Badan Pusat Statistik, 2021). This decline occurred in various tourist destinations in Indonesia, including in leading tourism destinations such as Yogyakarta, North Sulawesi, and East Nusa Tenggara.

The number of foreign tourist visits to the Special Region of Yogyakarta through the Adisutjipto Airport entrance in June 2019 reached 6,684 visits, compared to June 2018, the number of foreign tourist visits in June 2019 decreased by 11.44 percent. In June 2020 this figure dipped sharply, only 7 visits, this is better than April and May 2020 which had zero visits. Meanwhile, when compared to June 2019, the number of foreign tourist visits in June 2020 decreased by 99.89 percent. While in June 2021 there were no foreign tourist visits to D.I. Yogyakarta through the entrance of Yogyakarta International Airport (Badan Pusat Statistik Provinsi D.I. Yogyakarta, 2021).

Similar to the tourist destination of Yogyakarta, foreign tourist visits to North Sulawesi for almost two years of the pandemic are also facing great pressure. Data from the Central Bureau of Statistics of North Sulawesi shows that in June 2018 there were 10,107 foreign tourists visiting this region of Central Indonesia. 
The decline began to be seen in 2019, in June of that year only 8,342 foreign tourists came. Like Yogyakarta, 2020 was the lowest point in foreign tourist visits to North Sulawesi, which only amounted to 267 visits. In the middle of 2021 this number began to show an increase with the number of visits of 2,435 (Badan Pusat Statistik Provinsi Sulawesi Utara, 2021).

Extreme fluctuations in tourist visits also occurred in East Nusa Tenggara (NTT), which was indicated, among other things, by the number of guests staying at five-star hotels. Data from the Central Bureau of Statistics of NTT shows that in June 2018 there were 25,713 people, in June 2019 it increased to 32,801 people, while in June 2020 it fell to 6,152 people. The month of June 2021 showed encouraging signs with an increase in the number of guests staying up to 34,657 people (Badan Pusat Statistik Nusa Tenggara Timur, 2021).

The Covid-19 pandemic created a new era that had such a huge impact on mankind, which then caused human activities to be centered on digital devices and online platforms including the tourism industry (Kementerian Pariwisata dan Ekonomi Kreatif/Badan Pariwisata dan Ekonomi Kreatif Republik Indonesia, 2021). Expert Staff of the Minister for Organization, Management, and InterAgency Relations of the Ministry of Tourism and Creative Economy, Noor Hadi, encouraged tourism industry to take advantage of the power of social media to restore the tourism sector, through digital marketing, including social media that is widely accessed by the younger generation, to reach more consumers during pandemic (Yuniar, 2021).

Through various social media, Indonesian tourism stakeholders introduce various tourism objects and cultural wealth in various regions. During the Covid19 pandemic, digital platforms are even more powerful to transmit tourism information across space and time (Strategi Digital Tourism dalam Menggaet Wisatawan, 2021). When social media became popular, influencers are considered. Travel influencer such as Patricia Ranieta, Dimas Ramadhan, and Eka Situmorang, have been involved in popularizing the world of tourism in Indonesia (Mutiah, 2020).

Social media, influencers and their followers interact with each other and they, consciously or unconsciously, participate in weaving a culture of their own, a culture that Henry Jenkins calls participatory culture. Participatory culture is a concept that alludes to a kind of "culture in which fans and different shoppers are welcome to effectively take an interest in the creation and dissemination of new substance via web-based media. It is considered as an option in contrast to media power and something contrary to mass culture (Kavoura et al., 2019). Based on the explanation above, this study aims to describe cultural participatory in tourism digital communication promotion channel during the pandemic Covid-19, particularly in the micro influencer's Instagram accounts. This research is intended to contribute to the tourism sector, related to digital tourism communication.

This exploration via web-based media accounts these days is important because web-based media--or we call it social media--has been engaged with every day by computerized individuals, particularly when they are carrying on with their own business. It is because the use of digital channels with various apps in marketing and communication is a necessity for today's business (Taiminen \& 
Karjaluoto, 2015). The existence of various digital channels is becoming more important because it allows consumers and producers to interact in the marketing process (Çizmeci \& Ercan, 2015). On the other hand, the interaction that develops among the participants in these digital channels has become a culture that has its own characteristics, in the form of a participatory culture.

As indicated by Jenkins, Clinton, Purushotma, Robinson and Weigel (2006), the essential idea of participatory culture is a culture with a few supporting angles, including (1) There are generally low boundaries to imaginative articulation and local area association; (2) There is solid help for making and sharing what is made with others; (3) There is a sort of casual coaching that the most experienced individuals realize will show novices and beginners; (4) Members feel that their commitment is significant; and (5) Members feel some level of association with one another basically to the degree that they care regarding what others consider what they have made (DeMeo, 2016).

Those in a participatory culture feel that the work they add to the gathering is critical, and they additionally feel a social association with different individuals. There are regularly four participatory societies: alliance (affiliation), articulation (expression), cooperative critical thinking (collaborative problem solving), and flow (circulation). Alliance includes both formal and casual participation in an internet based local area, which might incorporate a Facebook bunch, message board, game ad, or different gatherings. Articulation incorporates inventive client produced content, which can appear as YouTube recordings, fan fiction stories, computer games, and so on. Shared critical thinking includes individuals cooperating to finish a job as in an elective reality game, or to file data, for example, accumulating a Wiki page. Ultimately, dissemination incorporates exercises that formed the progression of media, for example, through podcasting or publishing content to a blog (DeMeo, 2016).

The use of this concept has been carried out for years until it continues to experience development in various fields and has a virtual impact. According to Delwiche and Henderson, the influence is very broad, especially in the fields of education, politics, journalism, activism, and entertainment, and even marketing because community forums, exchange of ideas, knowledge cultivation and the growth of the movement (create movement) and distribution (share) between one party to another are formed in those areas. In other words, functions that were once hoarded by a small bunch of institutional chains of command (for example papers, TV channels, and colleges) have been looted by free distributors, video-sharing locales, cooperatively reasonable wellsprings of information, and fan-created diversion (DeMeo, 2016).

In the context of marketing, participatory culture refers to a type of "culture in which fans and different purchasers" are welcome to effectively partake in the creation and flow of new substance." It is considered as an option in contrast to media power and something contrary to mass culture. The intriguing viewpoint is that there is a difference between the meanings of 'fan' and 'consumer' because basically both terms are related to each other. The term of 'consumer' becomes an expression of someone who came or contacted cultural content before becoming a fan. Today's human identity is also built in the context of a consumer society. 
Starting here of view, the 'customer business' is seen as increasingly attractive in the form of well-known pictures, delights, dreams, and wants. As per Grossberg, the way that humans are associated with this attraction, either as consumers or enthusiasts, does not guarantee the consumer society's compliance with the interests or practices of the commercial sector. Sweetman, adding the explanation that once formed in groups as consumers or fans. The next step is the idea of building a subculture, and as what Jenkins coined as cultural exchange through content to construct a genuine post-social reality (Kavoura et al., 2019).

The essence of this participatory culture is, every part can make their own commitment, where new individuals can be directed by the people who have joined relatively long ago, to become part of a group that is expected to last for a long time. Interestingly, there is no concept of old and new members, so they are not vulnerable to competition because each member has the same rights and obligations. Another important element in distinguishing the participatory culture is about fans or the consumer community, which is also their strength is getting more power as consumers of cultural content, i.e. they act as content creators and at the same time consume them (Larabie, 2011). In other words, creating a 'prosumer' society that becomes a real form of connection between more available advanced innovations, made by internet users. It is also an acknowledgment that there has been a shift in the power relations between the media industry and its consumers.

In a study that used data sources from video-sharing platforms as a participatory cultural resource, such as YouTube, by Burgess and Green in 2009, the focus was more on "cultural and political questions: who can speak; who gets the attention; what compensation or rewards exist for creativity and work; and uncertainty surrounding various forms of expertise and authority" (Kavoura et al., 2019). The same research also explains that consumer co-creation is fundamental to YouTube's value proposition and the impact it can have on established media business models.

Another very important concept is being able to present a travel experience through YouTube which can be shared. It is considered a new idea that centres around the social rationale and social practices that empowered and advocated this new stage." This rationale clarifies that content sharing is a typical practice. In this manner, as per Jenkins, Ford and Green, the conversation is additionally identified with the act of scattering; utilization of spreadability or ability to be shared; the location as the objective for conveyance and the justification for why it was picked to appropriate specific sorts of content; financial designs that help or cut-off dissemination; qualities of text media that draw in local area inspiration to share material; and interpersonal organizations that associate individuals through the significant trade of data (Kavoura et al., 2019).

In addition, other important things that can be considered are "how important is the role in shaping the image of a destination or product in countering negative perceptions" as stated by Reino and Hay in 2016. Furthermore, the significance of web-based media in internet based travel data" as referenced by Xiang and Gretzel in 2010; "client produced content (UGC) via web-based media 
or shopper created content (CGC), shared on the webs, a stated by Hay, Page, and Buhalis in 2013 (Kavoura et al., 2019).

The use of this framework is is firmly identified with the utilization of new media. By realizing that internet technology has developed, the participatory aspect of culture has developed to become more conical to the true meaning of the concept of participation as mentioned by Robert in 2009 (Larabie, 2011). Consequently, much of the rhetoric around participatory culture does not consider how this form of participation encourages unexpected, as well as constructive, behavior and activities.

Arguments made about democratization or aspects of participation explicitly or otherwise are politicized as a participatory culture that can provide a new space for public conversation. Some people considered it as part of the public sphere. According to Deuze in 2008 and Turow in 2005, in the context of business, what should be noted is the inevitable inclusion of capital in this participatory culture. This will open access to control, power, and manipulation of personal information that is driven by the participation factor. Experts argue that the contribution of capital prompts inquiries of corporatization, restriction, and supervision so that it has the potential to lead to an economic boom (Larabie, 2011).

The internet has become the main tool for obtaining information and knowing the interests of individuals. This is very useful for marketers to know the potential value of their consumers. According to Joseph Turow in 2006 (Larabie, 2011), this process is referred to as marketing discrimination where consumers are labelled as things they like or don't like based on trends in economic potential. In conjunction with a participatory culture where personal information is easily obtained, it will be easier for marketers to get the economic value contained in individual users (Larabie, 2011).

\section{Research Methods}

This research is centered on digital media conducted by netnography. Netnography is applied with the consideration that this method makes it possible to collect data regarding human communication through computers or internets in detail down to the smallest part, which can reveal the unique habits of various computer or internet-mediated social interactions (Annisa, 2019).

Traditionally, netnography is applied to have a profound understanding of the marketplace and the actors who participate in it (Kristina \& Gustav, 2018). Data is usually collected and analyzed following the nature and rules that apply in the technological medium, in the form of technocultural artifacts (Kozinets, 2012). The netnography method in this study is carried out to describe digital tourism promotion activities carried out through social media, especially Instagram, within a period of three months, June to August 2021.

There are three selected social media accounts, focused on super-priority tourism destinations that have been chosen by the government. By using the Participatory Media Culture Theory from Henry Jenkins, we examine how audiences can play their roles as consumers and producers of media at the same time and create their own cultural commodities as meanings for existing media 
products and messages the data were gathered and analyzed by the social media analysis application Analysis.io. The subject of research is the influencers and followers in 3 Instagram accounts: @explorejogja, @ indraseptianazhari, and @ travelwithgerie, while the object of the research was the forms of participation as cultural artifacts in these accounts. These three accounts were chosen to represent traveling influencer in accounts from 3 super tourist destinations that consistently contain content about tourism in their area.

Data collection is carried out by observing the three social media accounts and using a social media analytic application, namely analysis.io to collect data online. The data collected is data from June to August 2021.

\section{Findings}

\section{Yogyakarta in the Instagram Account @explorejogja}

The @explorejogja account has a total of 749,829 followers, with more female followers than male followers, which is $63.64 \%$. This account is also followed by various age groups, but the highest recorded is the age range of 18-24 years with $47.27 \%$. As an account that specifically displays Yogyakarta from all points of view from culture, culinary, and various other tourism sectors, this account has followers located in various countries such as India, Australia, Spain, the United States, and of course most of them are in other countries. Indonesia itself.

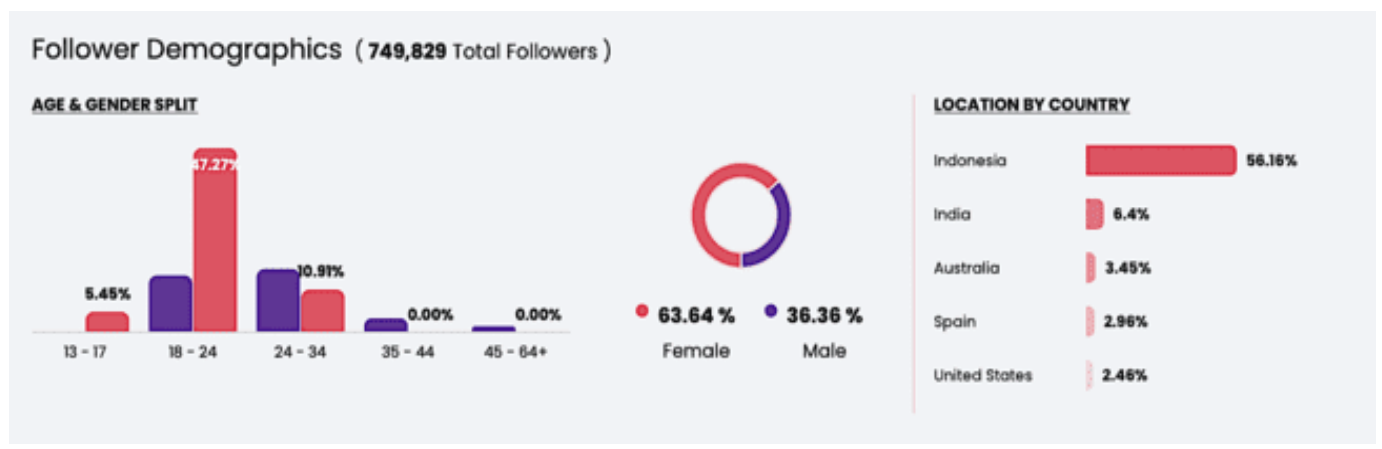

Figure 1: Follower Demographics of Instagram @explorejogja

(Source: Data Processing via analisa.io)

The form of participatory culture found in the @explorejogja account is mainly Affiliation and Expression (DeMeo, 2016). The affiliation that occurs is mainly supported by the aspect of supporting participatory culture which states that there are relatively low barriers to involving the community. The @explorejogja account even specifically provides space for the community to be involved in creating creative content about Yogyakarta. This is done by including their biographies explaining that by using a special hashtag, namely \#explorejogja, this account gets permission to re-post the original content into the @explorejogja account. 

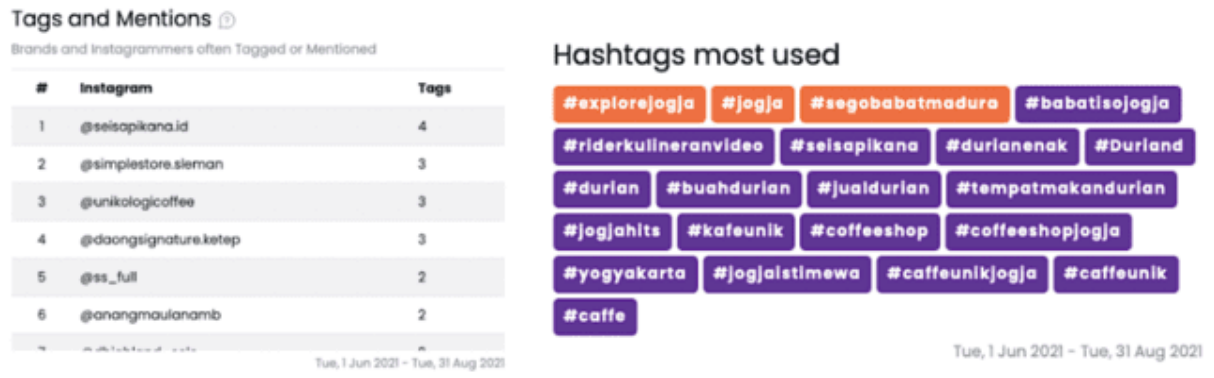

Figure 2: Tags, Mention, and Hashtags Most Used by @explorejogja (Source: Data Processing via analisa.io)

Most of the cultural artifact as content from the @explorejogja account is a repost of various content shared by both its followers and everyone who uses \#explorejogja. This affiliation occurs because this account also involves its followers as an informal form of membership. In doing re-posts, @explorejogja also gives credit by including the original account of the content creator.

Contents created by various groups are then reposted by @explorejogja in the form of videos or photos set in Yogyakarta. This is a form of participatory culture of expression because it includes creative content created by Instagram users, made by followers of @explorejogja and not followers. This form of expression is reinforced by a supportive aspect in a participatory culture which states that there is strong support for creating and sharing the content created.

The reposting of texts and artifacts played a major role in reshaping the relationship between its maker and audiences (Adami, 2014). Contents created by various groups are then reposted by @explorejogja in the form of videos or photos set in Yogyakarta. This is a form of participatory culture of expression because it includes creative content created by Instagram users, made by followers of @explorejogja and not followers. This form of expression is reinforced by a supportive aspect in a participatory culture which states relationship between participants as strong support for creating and sharing the content created.

\section{Most Viewed, Highest Engagement, Most Likes}

In the period June-August 2021, the content that gets Most Viewed, Highest Engagement, Most Likes is video content posted on August 4, 2021, and is the original content of the @adiojanoski account that uploaded the video on TikTok. This video depicts a traditional angklung music performance that is performed on Malioboro street so that it can be seen by all visitors who pass by on the street.

The caption written by @explorejogja which is "want to ask 'do you miss this' but is afraid of being criticized by netizens" shows that the show in the video has not been done for a long time since the Covid-19 pandemic. Some of the comments that appear in this upload also show how the outbreak of Covid-19 has greatly affected various facets of life, including tourism. The high interaction on this upload shows that people are interested in the content in the video which can indeed describe how the atmosphere on Malioboro Street was before the pandemic hit. 

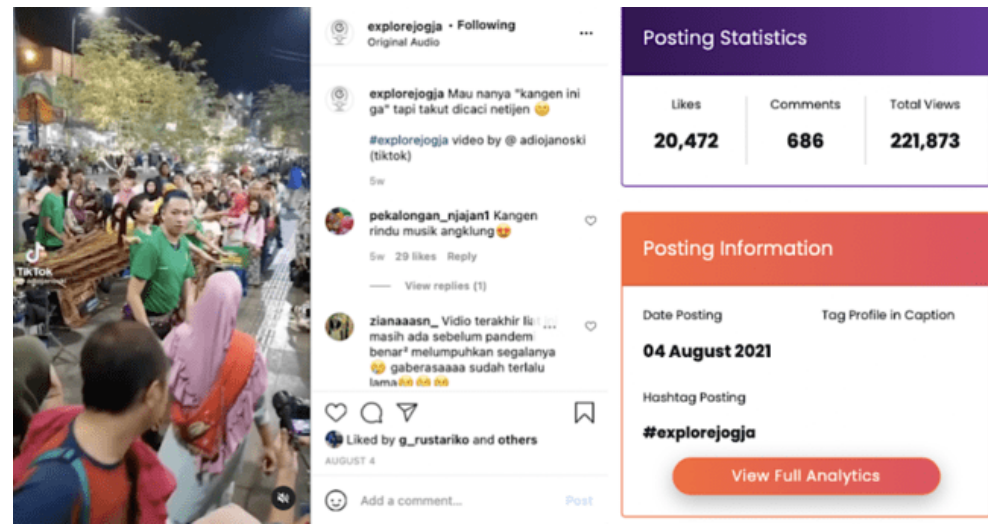

Figure 3: Tagged - Most Viewed, Highest Engagement, Most Likes (Source: Instagram https://www.instagram.com/p/CSJo3ArJKYP/ and Data

Processing via analisa.io)

\section{Most Commented}

In the three-month period, the content that got the most comments were the video content posted on June 15, 2021. The original owner of this content is the account @_dhitapermataa who took the video at Midodaren Beach, Gunungkidul. The video in this content shows the owner of the content sitting on the beach with a tent that is also set up in the same place, but he seems to be on a cliff.
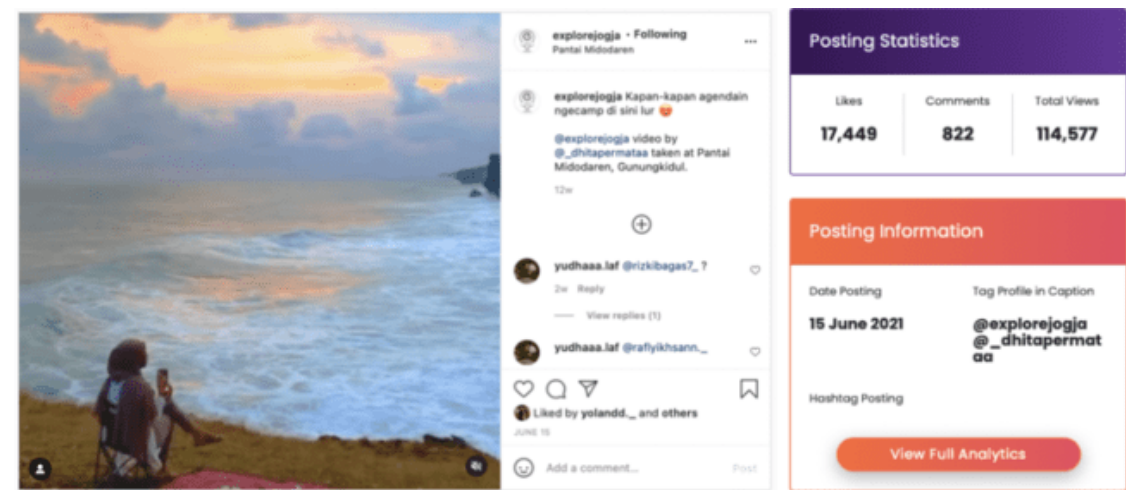

Figure 4: Tagged - Most Commented

(Source: Instagram https://www.instagram.com/p/CQI2bhbDE5x/ and Data

Processing via analisa.io)

The caption given by @explorejogja which is "anytime do you want to camp here, please" shows an invitation to come and camp at Midodaren beach. As the upload with the most comments, most of the comments are also an invitation to come to the beach, even most of them make comments tagged to their friend groups so that this content is increasingly widespread. The number of comments that appear by sharing this information with others shows that there is an interest in the location of Midodaren beach which is quite different from other beaches because the area is rocky and quite unique as a beach tourism location in Yogyakarta. From this upload, it can also be seen that there is a participatory culture where users who 
see this upload also redistribute it. This again demonstrates the importance of social media in information about tourism, especially travel as mentioned by Xiang and Gretzel (Kavoura et al., 2019), either as user-generated content (UGC) on social media or consumer-generated content (CGC) shared online.

\section{Labuan Bajo in the Instagram Account @indraseptianazhari}

Instagram account @indraseptianazhari has a total of 5,628 followers, mostly aged between $18-24$ years, $75 \%$ of his followers are women. This account belongs to a photographer in Labuan Bajo, East Nusa Tenggara, and is affiliated with a travel agency in the same location, named vincavoyages (@indraseptianazhari, 2021).

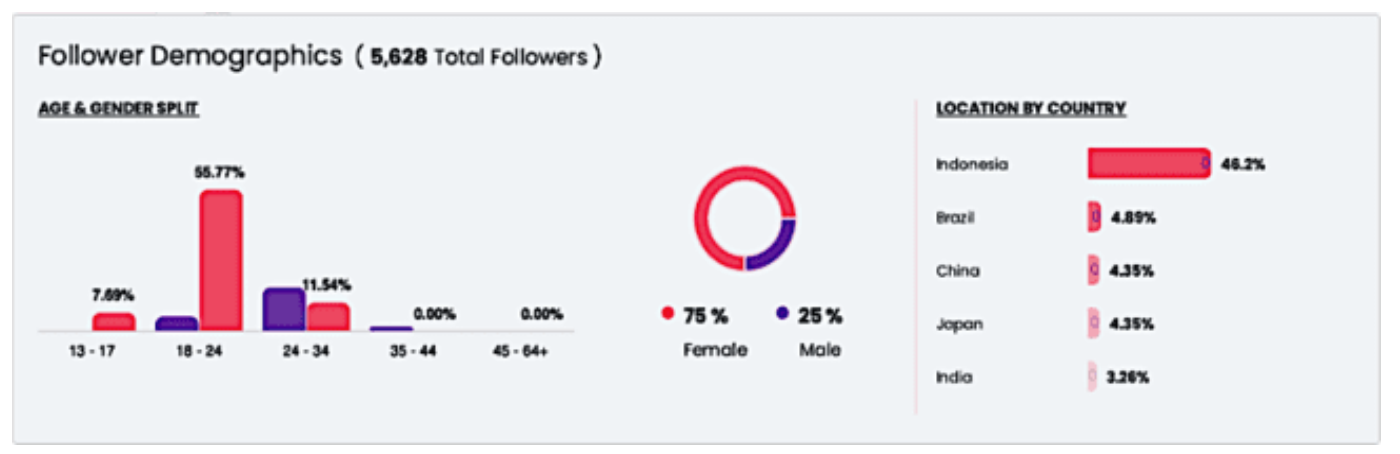

Figure 5: Followers Demographics of @indraseptianazhari (Source: Data Processing via analisa.io)

The initial characteristics of participatory culture in this account can be seen from the relatively low barriers for the community to be involved (DeMeo, 2016), generally only starting with becoming a follower, involvement starts from just seeing, giving appreciation or expressing love with a click of a heart, and comment in the "chat" column. Strong support for sharing posts to a network of friends from followers can be seen from the sharing feature that is provided in the Instagram application. This provides an opportunity for spreadability or capacity for content within these accounts to be shared (Kavoura et al., 2019). Informal guidance (DeMeo, 2016) in this account mostly comes from the account owner, who in addition to sharing pictures of the natural beauty of the Labuan Bajo tourist destination with human subjects enjoying the beauty of nature, also conveys a form of reflective messages cultural artifact such as informal guidance about life in narrative form, such as: "Hope is the only thing stronger than fear" (@indraseptianazhari, 2020c); "Good days give you happiness, bad days give you experience" (@indraseptianazhari, 2020a); and "You only live once, make the most of it" (@indraseptianazhari, 2020b).

\section{Most Viewed and Commented Tagged of Artistic Videography and Narrative Life Reflections of An Endorser Member}

Participatory culture in Instagram accounts can also be seen through the importance of contributions and the degree of social relations with each other, at least concern with what other people think about what they have created (DeMeo, 
2016), which is reflected among others through the tag feature. Tags allow members to make their personal contributions to their own content and tag them so that they can be seen by the admin of the intended Instagram account and other members. Further member participation and interaction occurs when other members comment on each other's content. A reflection of the peak of this form of participation can be seen in the tagged content that is most viewed and commented on by other members.

From June to August 2021 tagged cultural artifact content from members that was seen and commented on by other members was the video tagged by the account@yuliismyantizain, this video was viewed 1,291 times, liked by indraseptianazhari, and commented on by 4 followers/members @ indraseptianazhari. In addition to showing the beauty of one of the locations in Labuan Bajo, this video shows the artistic taking of pictures of the account owner accompanied by background music that reinforces the artistic value of the video. In addition, this video is accompanied by a text narration cultural artifact in the same stream as@indraseptianazhari, in the form of a life reflection "One of the bravest decisions you have ever made is to let go of what hurts your heart and soul, the spirit of self-healing fighters" (@yuliismayantizain, 2021)

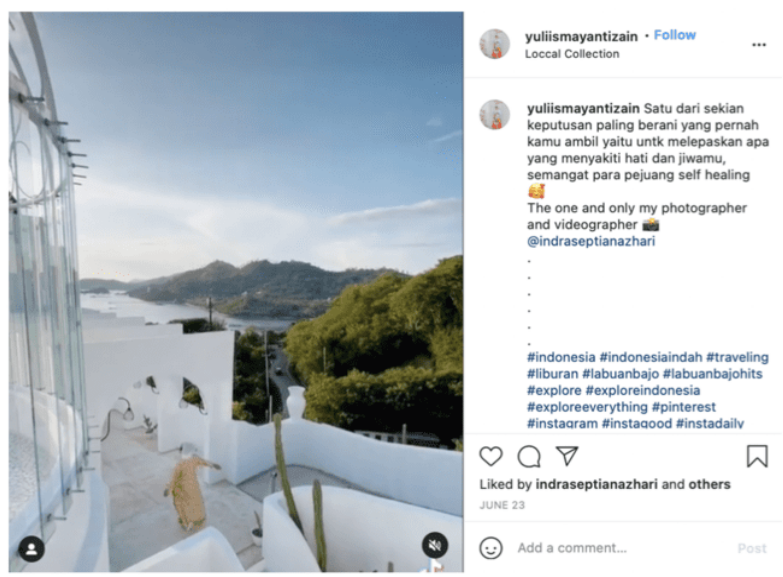

Figure 6: Tagged - Most Viewed

(Source: Instagram https://www.instagram.com/p/CQc98pNBP2R/)

Data analysis through Analysis.io revealed that @yuliismyantizain is an endorser, a micro influencer, who has 13,441 followers, with an average engagement of 212, 201 likes and 11 comments per post, a significant number (https://analisa.io/profile/yuliismyantizain) Here we can see the uniqueness of the relationship between the owner of the @indraseptianazhari account and its followers/members, on the one hand the owner of the @yuliismyantizain account is a consumer of content produced by @indraseptianazhari at the same time as one of the content producers tagged into the account. The participatory culture of fans or the consumer community is thus, at the same time their advantage is getting more power as consumers of cultural content, i.e., they act as content creators and at the same time consume them (Larabie, 2011). In other words, creating a 'prosumer' society that becomes a real form of connection between digital technology that is 
more accessible, made by internet users, where the main commodity is the beauty of Labuan Bajo videography, endorsers and life reflection narratives that allow tourism promotion to continue to resonate.

\section{Most Likes Tagged Content by A Gym Freak Digital Creator Endorser}

Another form of participatory culture that exists in this account can be seen in tagged content that gets likes from other account members. During 3 (three) months of data collection, the user content that received the most likes was the upload of @bang_dhiztra, which received 1,366 likes. @bang_dhistra's upload displays a photo of himself at one of Labuan Bajo's tourist attractions. @bang_ dhistra identifies himself as a digital creator who is a gym freak, he is also a micro influencer. In July 2021 his account followers numbered 19,643. In his personal account, bang_dhiztra quite often gets more than 1000 likes, with an average like of 1,031 per post, an engagement rate of $5.41 \%$ and a like rate of $5.25 \%$. The most used hashtags were about gym and fitness, while the hashtags \#triplabuanbajo, \#explorelabuanbajo, \#travelerlabuanbajo, and \#labuanbajoexpolre were included as the 21 hashtags he used the most (https://analisa.io/profile/bang dhiztra).

@bang_dhiztra reflects informal affiliation/membership within the community in the @ Instagram account @indraseptianazhari. The content tagged by @bang_dhiztra is an expression of creative user-generated content in the form of photos (DeMeo, 2016). This photo tag from @bang_dhiztra also shows that as a member he not only consumes the content in the @indraseptianazhari account, but as a member of the virtual community he has the power as a content creator to (Larabie, 2011), as part of the culture of the prosumer community.

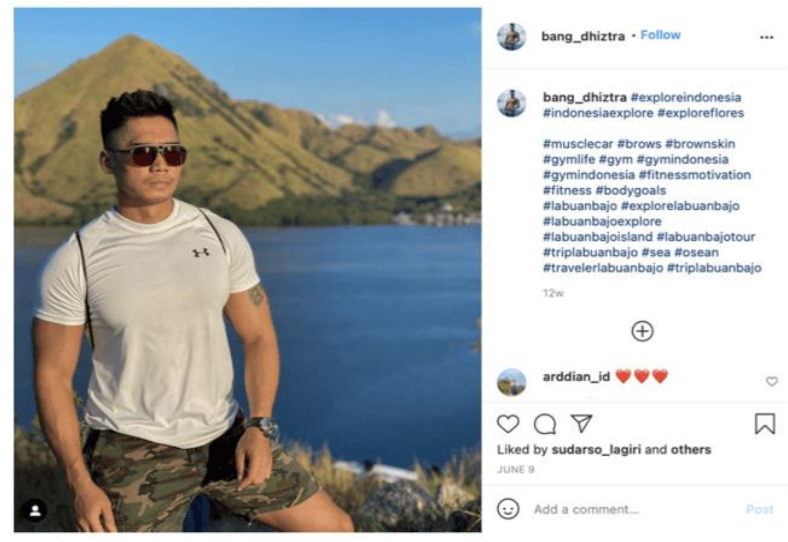

Figure 7: Tagged - Most Likes

(Source: Instagram https://www.instagram.com/p/CP49Y5Hr2SC/)

According to Jenkins, Ford, Green, based on social logic and cultural practices in virtual communities, likes to content tagged by @bang_dhiztra as influencers who have many followers, as well as prosumers, have the ability to practice dissemination; spreadability or capacity to be shared, complete with text media attributes that attract community motivation to share material; and social networks that connect people through meaningful exchange of information 
(Kavoura et al., 2019). Likes from followers at least double the spread of content that inspires love for content about Labuan Bajo.

Likes show the attitudes of other virtual community members and have the opportunity to develop through e-wom mechanisms in virtual communities (Sánchez-Torres et al., 2018). Moreover, within social media is a form of communication that signals validation and approval with one click, without having to type anything. This seemingly very simple and basic feature is one of the most powerful online tools ever created. Likes allow users to quickly understand how popular or relevant a post is without having to read all the comments (Moffat, 2019), to be an indication of potential commodities for participants. Likes on content from endorsers who are digital creators and gym freaks who have quite a few followers open wide opportunities for more information and positive attitudes towards Labuan Bajo, even during the pandemic.

\section{Likupang in the Instagram Account @ travelwithgerie}

@ travelwithgerie is an Instagram account about Likupang travel destination that has 1227 followers is, its total post is 70 , the engagement rate is $15.93 \%$, the like rate is $15.49 \%$, while the comment rate is $0.44 \%$. Most, or $59.14 \%$ of the followers of this account are between 18-24 years old, while $49.57 \%$ of the followers are women, as represented in Figure 3 (analisa.io).

For three months, from June to August 2021, one form of participatory culture was found in the form of expressions on the @ travelwithgerie account, where according to (DeMeo, 2016) expressions include user-generated creative content. In this case, the creative content that appears is photo uploads on Instagram social media that consumers do by marking (tag) @ travelwithgerie in their uploads. This tag activity emphasizes the supporting aspects of participatory culture conveyed by (DeMeo, 2016) that the barriers to engaging and expressing artistically are relatively low. In other words, audiences can easily participate in expression and create their cultural commodities.

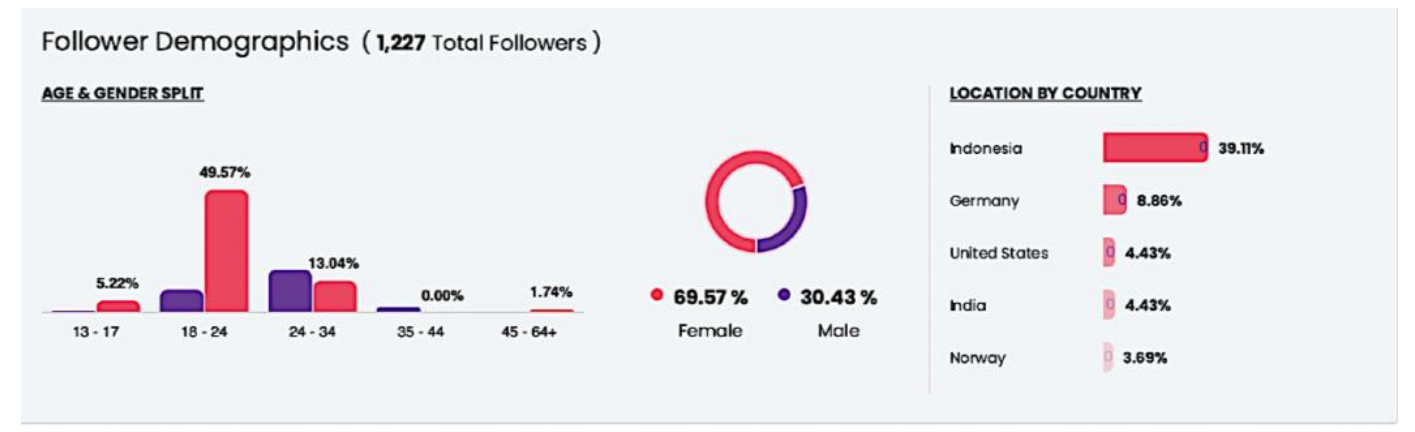

Figure 8: Followers Demographics of @ travelwithgerie (Source: Data Processing via analisa.io) 


\section{Most Commented}

It is indicated that there are two uploads that tag @ travelwithgerie which have attracted the most attention from other audiences. The first upload received the most comments, namely 15 . The visual shown is a woman posing on Lihaga Island, Likupang, North Sulawesi. The producer of this post has the username @itsria_jacob. In such a way the upload is generated, then a caption is attached, namely "The beach has its charm that makes us always long to come back."

The combination of visually attractive uploads and good caption writing certainly contributes to the dissemination of information related to Likupang's super-priority tourist destinations. Tourism digital communication is carried out by @ itsria_jacob who is a prosumer who participates in the formation of new cultural commodities. In addition to the many comments, this upload also received 122 likes. All comments given by the audience were also positive, consisting of praise and smiles or like emojis.

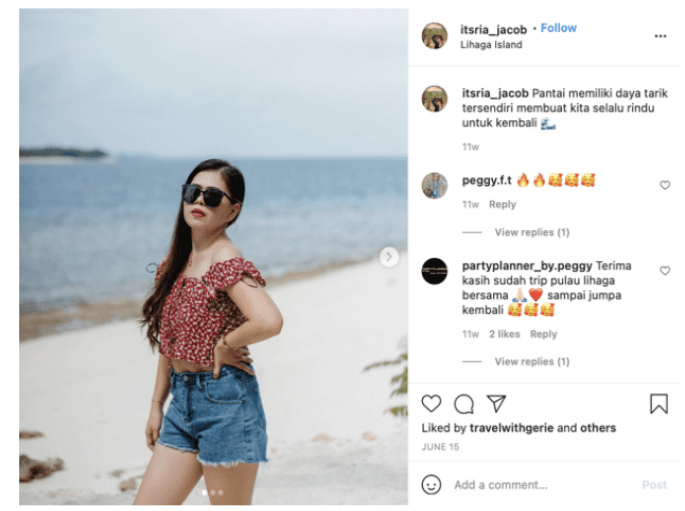

Figure 9: Tagged - Most Commented

(Source: Instagram https://www.instagram.com/p/CQJazlBgkeG/)

\section{Most Likes}

Furthermore, the expression of creative content was also carried out by @ partyplanner_by.peggy which is owned by a micro-influencer, @ peggy.f.t. This micro-influencer has 6,644 followers on his Instagram account. On his account, he describes herself as a creator, and if examined further he is an entrepreneur. Her business is quite diverse with its core business, namely GG Group. Under the auspices of the GG Group, there are businesses in fashion, jewelry, fragrances, and party planners.

Influencer marketing and social media are inherently intertwined, while influencers need the exposure provided by social media platforms to be more recognizable, and those platforms achieve at least part of their appeal through content posted by influencers who are active on them (Haenlein et al., 2020).

In this post, micro-influencers offer artistic cultural artifacts, while still expressing their identity and marketing intentions in participating in this tourism account. The photo uploaded by @partyplanner_by.peggy again shows the beauty of Lihaga Island which is being enjoyed by several tourists. Marking @ travelwithgerie in this photo, @partyplanner_by.peggy is also a prosumerwho 
not only produces cultural commodities in the form of creative content but also opens private trip services in the tourist area of Likupang. Actively participating in the creation and distribution of new content, @ partyplanner_by.peggy takes a role in fostering a positive image of the Likupang destination, in line with what Reino and Hay said in 2016 about the importance of digital tourism communication (Kavoura et al., 2019).

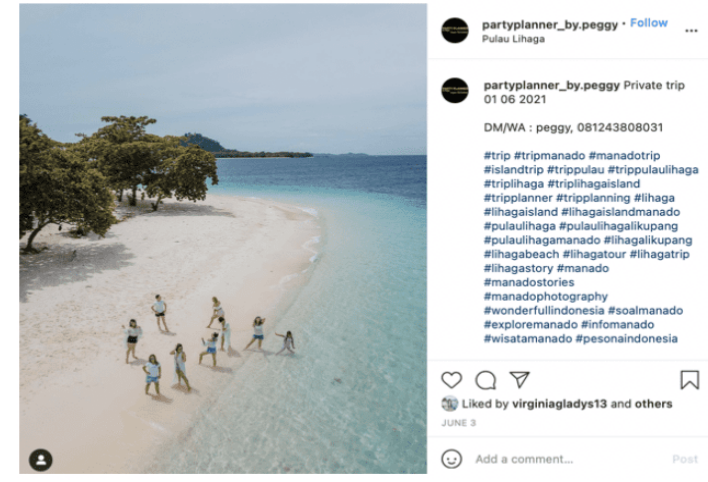

Figure 10: Tagged - Most Likes

(Source: Instagram https://www.instagram.com/p/CRCA9nJDejS/)

Social media is an important channel for disseminating tourist information (Kavoura et al., 2019), so the upload of @ partyplanner_by.peggy becomes an integral form of participatory culture in tourism digital communication efforts, especially the super-priority destination Likupang on the Minahasa Coast.

\section{Discussions}

The analysis above shows how the use of digital channels allows consumers and producers (and even prosumers) to interact with each other in the marketing process (Çizmeci \& Ercan, 2015). At the same time their interaction develops into a culture that has its own characteristics as a participatory culture. The three accounts both apply a participatory culture in their respective content although in different ways. The @ explorejogja account which promotes more natural, artificial, and culinary tourism areas in Yogyakarta and surrounding areas, chooses to implement all its content originating from submissions from third parties (contributors), whether as its followers or not. Even during the research period, no original content was found by the account owner. As long as what is found is only content marketing in the form of sponsored ads that aim to promote the product.

In @explorejogja reposting is a major cultural artifact, where of texts and artifacts played a major role in reshaping the relationship between its maker and audiences (Adami, 2014). By filling in the material submitted to outsiders or contributions from followers or not, this account owner or administrator does not need to spend large amounts of money on its content strategy. They are only required to mention the name of the social media account that sent the material. Regarding compensation, it is not yet known what form of transaction or compensation was made between the account owner and the contributors. 
This is a little bit different from the content strategy applied to the @ indraseptianaazhari account, which is actively filling social media material with personal works because of his profession as a photographer, the forms of cultural artifacts appear in artistic photography and narrative of life reflections.

The participatory culture that appears on this account is the proliferation of forms of appreciation, expression, and comments from followers. This is the main aspect needed in the concept of Culture Participatory which is the result of Henry Jenkins' thinking (DeMeo, 2016). The existence of this interaction results in a bond between the account owner and his followers organically or naturally so that they do not realize when the account owner gives a 'sponsored message' or commonly known as soft marketing. This is considered normal because human identity is positioned as a consumer society. After being formed as consumers, then a mutually agreed subculture is created and there is also a cultural exchange between account owners and followers through interesting cash (Kavoura et al., 2019).

Another form of participatory culture that is also applied as a digital tourism promotion strategy is using tags or markers. This applies to the Instagram account $@$ travelwithgerie, where this account has been mentioned several times by several of its followers. This activity is in line with the opinion of (DeMeo, 2016) that audiences can easily participate in expression and create their own cultural commodities. When the participants are influencers marketing, the relationship between these influencer participants reinforces the prosumer culture artifact that is built, given that influencers need the exposure provided by social media platforms to be more recognizable, while for these platforms the attractiveness of content posted by influencers who are active on social media adds the appeal of the account itself (Haenlein et al., 2020).

This gives power to the followers of the account, where they can act as consumers of content produced by the @ travelwithgerie account owner, but on the other hand, they are also able to act as content creators. This is a participatory culture that can form a prosumer society that is able to carry out two functions at once on its social media accounts. On one occasion they become consumers, but on another occasion in the same stall, they are equal to account owners and are able to carry out their functions as managers of the media industry (Larabie, 2011).

\section{Conclusions}

This research concludes that, in the context of digital marketing communications, the participants build a participatory culture with the power of visual and narratives artifacts, as well as their spreadability.

It is further concluded that (1) cultural artifacts in each account have their own characteristics, with similarities to prosumer participation, where reposting becomes a cultural artifact that has its own power to form virtual relationships; (2) attractive visuals and informal guides in the form of narratives are also cultural artifacts that can invite further involvement of participants, in the form of likes, comments, reposts, etc.; and (3) the presence of micro-influencers who are inherently intertwined with these accounts jointly contributing to the dissemination 
of content and their respective accounts, which in turn becomes a force for the spread of tourism marketing, especially during the Covid-19 pandemic.

\section{Acknowledgment}

Ministry of Education, Culture, Research and Technology, Institute for Research and Community Service Tarumanagara University, @explorejogja, @indraseptianazhari, @travelwithgerie, @yuliismyantizain, @bang_dhiztra, @_dhitapermataa, @adiojanoski, @itsria_jacob, @ partyplanner_by.peggy.

\section{References}

@indraseptianazhari. (2020a). Hari baik memberimu kebahagiaan. hari buruk memberimu pengalaman. Instagram. https://www.instagram.com/p/CBJppTLFDcC/?utm_medium=copy_link

@indraseptianazhari. (2020b). Hidup hanya sekali,manfaatkan sebaik mungkin. Instagram. https://www.instagram.com/p/CAoOEjnFarb/?utm_medium=copy_link

@ indraseptianazhari. (2020c). Hope is the only thing stronger than fear. Instagram. https://www.instagram.com/p/CB4Z1AfFv8U/?utm_medium=copy_link

@indraseptianazhari. (2021). No Nitle. No Instagram. https://www.instagram.com/indraseptianazhari/?utm_medium=copy_link

@yuliismayantizain. $\quad$ (2021). $\quad$ Instagram. https://www.instagram.com/p/CQc98pNBP2R/

Adami, E. (2014). Retwitting, Reposting, Repinning; Reshaping Identities Online:Towards a Social Semiotic Multimodal Analysis of Digital Remediation. LEA - Lingue e Letterature d'Oriente e d'Occidente, 3, 223 243. https://doi.org/http://dx.doi.org/10.13128/LEA-1824-484x-15194

Annisa, S. (2019). Studi Netnografi Aksi Beat Plastic Pollution Oleh United Nations Environment di Instagram. ASPIKOM, 3(6). https://doi.org/http://dx.doi.org/10.24329/aspikom.v3i6.411

Badan Pusat Statistik. (2021). Jumlah Kunjungan Wisman ke Indonesia. https://www.bps.go.id/pressrelease.html?katsubjek=16\&Brs\%5Btgl_rilis_i nd $\% 5 \mathrm{D}=\& \mathrm{Brs} \% 5 \mathrm{Btahun} \% 5 \mathrm{D}=\& \mathrm{yt} 0=$ Cari

Badan Pusat Statistik Nusa Tenggara Timur. (2021). Berita Resmi Statistik. https://ntt.bps.go.id/pressrelease.html?katsubjek=16\&Brs\%5Btgl_rilis_ind $\% 5 \mathrm{D}=\& \mathrm{Brs} \% 5 \mathrm{Btahun} \% 5 \mathrm{D}=\& \mathrm{yt} 0=$ Cari

Badan Pusat Statistik Provinsi D.I. Yogyakarta. (2021). Perkembangan Pariwisata dan Transportasi Udara Daerah Istimewa Yogyakarta. https://yogyakarta.bps.go.id/pressrelease.html?katsubjek=16\&Brs\%5Btgl_ rilis_ind $\% 5 \mathrm{D}=\& \mathrm{Brs} \% 5 \mathrm{Btahun} \% 5 \mathrm{D}=\& \mathrm{yt} 0=\mathrm{Cari}$

Badan Pusat Statistik Provinsi Sulawesi Utara. (2021). Perkembangan Pariwisata Sulawesi Utara. https://sulut.bps.go.id/pressrelease.html?katsubjek=16\&Brs\%5Btgl_rilis_i nd $\% 5 \mathrm{D}=\& \mathrm{Brs} \% 5 \mathrm{Btahun} \% 5 \mathrm{D}=\& \mathrm{yt} 0=\mathrm{Cari}$ 
Çizmeci, F., \& Ercan, T. (2015). The Effect of Digital Marketing Communication Tools in the Creation Brand Awareness By Housing Companies. MEGARON, 10(2), 149-161. https://doi.org/10.5505/MEGARON.2015.73745

DeMeo, E. (2016). Fandom and Social Media Marketing Looking at "Doctor Who" Tumblr Engagement Through the Lens of Participatory Culture. https://www.proquest.com/openview/231d0ff7d69d2bbe333d313a80219ba $1 / 1$ ?pq-origsite $=$ gscholar $\& \mathrm{cbl}=18750$

Haenlein, M., Anadol, E., Farnsworth, T., Hugo, H., Hunichen, J., \& Welte, D. (2020). Navigating the New Era of Influencer Marketing: How to be Successful on Instagram, TikTok, \& Co. California. Management Review, 63(1), 5-25. https://doi.org/https://doi.org/10.1177/0008125620958166

Kavoura, Androniki, Kefallonitis, Efstathios, \& Theodoridis (Eds.). (2019). Strategic Innovative Marketing and Tourism. In The proceedings of the International Conference on Strategic Innovative Marketing and Tourism (ICSIMAT).

Kementerian Pariwisata dan Ekonomi Kreatif/Badan Pariwisata dan Ekonomi Kreatif Republik Indonesia. (2021). Tren Pariwisata Indonesia di Tengah Pandemi. https://kemenparekraf.go.id/ragam-pariwisata/Tren-PariwisataIndonesia-di-Tengah-Pandemi

Kozinets, R. V. (2012). Marketing Netnography: Prom/ot(Ulgat)ing a New Research Method. Methodological Innovations Online, 7(1), 37-45. https://doi.org/https://doi.org/10.4256/mio.2012.004

Kristina, H., \& Gustav, M. (2018). Netnography as a tool for understanding customers: implications for service research and practice. Journal of Services Marketing, 32(6), 657-679. https://doi.org/10.1108/JSM-08-20170294

Larabie, C. (2011). Participatory Culture and the Hidden Costs of Sharing. The McMaster Journal of Communication, 7(1), 66-88. https://journals.mcmaster.ca/mjc/article/view/255/222

Moffat, B. (2019). The power of likes on social media: Friend or foe? The Future of Customer Engagement and Experience.

Mutiah, D. (2020). Kemenparekraf Gandeng 11 Influencer Promosikan Destinasi Wisata Berbasis CHSE. Www.Liputan6.Com. https://www.liputan6.com/lifestyle/read/4383749/kemenparekraf-gandeng11-influencer-promosikan-destinasi-wisata-berbasis-chse

Putra, R. A. (2017). Fungsi media sosial Instagram dalam meningkatkan minat wisatawan Glamping Lakeside. Deutsche Welle. https://www.dw.com/id/potensi-kerugian-pariwisata-akibat-corona/a52735305

Sánchez-Torres, J. A., Montoya, L. A., \& Potes-Arce, P. (2018). Behind the likes, content and brand on Instagram. SUMA DE NEGOCIOS, 9(19), 17-24. https://doi.org/https://doi.org/10.14349/sumneg/2018.v9.n19.a3 
Riris Loisa, Diah Ayu Candraningrum, Lusia Savitri Setyo Utami, Lydia Irena:

Cultural Participatory in Tourism Digital Marketing Communication Channel

Budaya Partisipatori dalam Saluran Komunikasi Pemasaran Digital Pariwisata

Strategi Digital Tourism dalam Menggaet Wisatawan. (2021). Kementerian Pariwisata Dan Ekonomi Kreatif / Badan Pariwisata Dan Ekonomi Kreatif Republik Indonesia. https://kemenparekraf.go.id/ragampariwisata/Strategi-Digital-Tourism-dalam-Menggaet-Wisatawan

Taiminen, H. M., \& Karjaluoto, H. (2015). The usage of digital marketing channels in SMEs. Journal of Small Business and Enterprise Development, 22(4), 633-651. https://doi.org/10.1108/JSBED-05-2013-0073

Yuniar, N. (2021). Manfaatkan Media Sosial untuk Bangkitkan Pariwisata. Kantor Berita ANTARA. https://www.antaranews.com/berita/2220890/manfaatkan-media-sosialuntuk-bangkitkan-pariwisata 